\title{
As comemorações de Tiradentes: memória e identidade de gênero na Polícia Militar do Paraná
}

Andréa Mazurok Schactae'

A Proclamação da República no Brasil, em 1889, marcou o início de um processo de construção de heróis nacionais. Os republicanos, segundo José Murilo de Carvalho, iniciaram uma tentativa de transformar os principais personagens do movimento que levou ao fim da monarquia em heróis. Os candidatos a ocupar tal condição foram Benjamim Constant, Marechal Deodoro e Marechal Floriano Peixoto, porém estes não tinham grande reconhecimento histórico, se comparados a outros heróis militares, como Caxias, Osório e Tamandaré. O escolhido, por fim, foi o Alferes Joaquim José da Silva Xavier, o Tiradentes, que viveu em Minas Gerais, no século XVIII, e foi o único homem, entre os envolvidos na Inconfidência, a ser condenado à morte. Em meados do século XIX já se havia escrito a primeira história da Inconfidência e em 1859 Tiradentes era descrito com as características de um herói: um homem que morreu enforcado e teve seu corpo esquartejado em nome da liberdade. Seu sacrificio já era identificado ao de Cristo anos antes da Proclamação da República. Em 1890, o dia de sua morte foi declarado feriado nacional e nos primeiros anos do século XX, Tiradentes foi transformado em herói nacional. ${ }^{2}$

Herói construído pela República para representar a nação, tornou-se um modelo de cidadão, que foi sucessivamente reconstruído, em função das necessidades impostas ao longo do século XX. Suas faces são a de Cristo, a do mi-

\footnotetext{
${ }^{1}$ Doutoranda em História da Universidade Federal do Paraná (UFPR/CAPES). ${ }^{2}$ CARVAlHO, José. M. de. A formação das almas: o imaginário da República no Brasil. São Paulo: Cia das Letras, 1998, p. 55-73. 
litar, a do cidadão e possivelmente outras, dependendo da identidade que deve encarnar.

Os heróis construídos pelos Estados corporificam ideias, justificam práticas e constroem referenciais identitários coletivos, que são reconstruídos de acordo com as necessidades. Para Maria Milliet, os cultos a heróis são invenções que estão vinculadas à ideia de nação e "a heroicização do Tiradentes sob a égide da República não é um acaso histórico; antes, constitui criação objetiva que visa identificá-lo como Protomártir da Independência e da República, fazendo dele um dos Pilares da nacionalidade". ${ }^{3}$ Ele se tornou, portanto, um modelo a ser seguido.

Submetido a esse processo de construção e reconstrução, Tiradentes assumiu diferentes faces no decorrer do século XX. Em 1946, o Presidente Eurico Gaspar Dutra sancionou o decreto-lei que o instituiu Patrono das Polícias Civis e Militares. Escolhido entre "os grandes homens da história"4, segundo o texto da lei, ele ganhou mais uma identidade, a de policial.

(...) considerando que entre os grandes homens da história pátria que mais se empenharam pela manutenção da ordem interna, avulta a figura heroica de Joaquim José da Silva Xavier (Tiradentes) (...) [e] que a ação do proto-mártir da Independência, como soldado da Lei e da Ordem, deve constituir um paradigma para os que hoje exercem funções de defesa da segurança pública, (...). Fica instituído o Dia das Polícias Civis e Militares que será comemorado todos os anos a 21 de abril (...). ${ }^{5}$

Esse fragmento do texto do decreto tem a intenção de justificar o motivo por que o herói mineiro da Inconfidência foi instituído como um exemplo a ser seguido pelos policiais. O homem soldado da lei e da ordem é um modelo para aque-

${ }^{3}$ MILliET, Maria Alice. Tiradentes: o corpo do herói. São Paulo: Martins Fontes, 2001, p.17-19.

${ }^{4}$ BRASIL. Decreto-lei n. 9.208 de 29 de abril de 1946. In: POLÍCIA MILITAR DO ESTADO DOPARANÁ. Boletim Geral, Curitiba, PR, n. ${ }^{\circ}$ 105, 09 de maio de 1946. ${ }^{5}$ BRASIL. Decreto-lei n. 9.208 de 29 de abril de 1946. In: POLÍCIA MILITAR DO ESTADO DOPARANÁ. Boletim Geral, Curitiba, PR, n. ${ }^{\circ}$ 105, 09 de maio de 1946. 
les que exercem a função de segurança pública. No início da Ditadura Militar (1964-1985), no ano de 1965, o governo militar sancionou a Lei que tornou Tiradentes "o patrono cívico da nação brasileira", ${ }^{6}$ investindo o herói na condição de pai da nação. Reafirmava-se o a figura militar do Alferes, fundada em um ideal de masculinidade, fato que também está presente em outros heróis da República analisados por José Murilo de Carvalho ${ }^{7}$ e também heróis do Exército, objetos de estudo de Celso Castro ${ }^{8}$.

Uma República que foi instituída pelas Forças Militares construiu, assim, um herói que representa o militar, o religioso, o povo e a masculinidade. As múltiplas faces desse herói possibilitam, como dissemos acima, sua constante reconstrução e adaptação às diferentes realidades institucionais, politicas e sociais. Para os militares, a identidade do herói assume principalmente a face do Alferes, o soldado que morreu em defesa da Pátria. Sua imagem é a de um homem que lutou pela liberdade da Pátria contra os tiranos portugueses.

Esse herói contraditório e multifacetado é um personagem que possibilita problematizar a construção de identidades e memórias institucionais, as quais existem em relação a uma identidade nacional e são marcadas também por questões de gênero. Isto é, os heróis são símbolos que incorporam os significados socialmente construídos sobre as diferenças sexuais e representam os espaços de poder ocupados por homens e mulheres no Estado e nas instituições. Eles são veículos de transmissão e perpetuação de identidades coletivas fundadas nas diferenças sexuais socialmente construídas e naturalizadas nas relações sociais e nos símbolos. ${ }^{9}$

\footnotetext{
${ }^{6}$ CARVALHO, José. M. de. A formação das almas: o imaginário da República no Brasil. São Paulo: Cia das Letras, 1998, p.71.

${ }^{7}$ CARVALHO, José. M. de. A formação das almas: o imaginário da República no Brasil. São Paulo: Cia das Letras, 1998.

${ }^{8}$ CASTRO, Celso. Entre Caxias e Osório: a criação do culto ao patrono do Exército Brasileiro. Estudos Históricos. Rio de Janeiro, v. 14, n. ${ }^{\circ}$ 25, 2000. Disponivel em: $<$ wwwcpdocfgvbrrevistaarq286.pdf > ... Acesso em: 03/10/2008.

${ }^{9}$ SCOTT, Joan W. Gênero: uma categoria útil de análise histórica. Educação e Realidade, v. 20, n. ${ }^{\circ}$, 1995, p. 71-99. 
Levando em conta tais aspectos, o objetivo deste artigo é analisar as Ordens do Dia dedicadas ao Tiradentes ${ }^{10}$ na Polícia Militar do Paraná, entre 1977 e 1983, como espaço de constituição e permanência de uma memória e de uma identidade institucional generificada. Toma-se como recorte temporal duas alterações na estrutura institucional, ambas ocorridas nos últimos anos da Ditadura Militar. A primeira é a criação do Pelotão de Polícia Feminina no Paraná, no ano de 1977; e a outra é a nomeação de um Coronel da Polícia Militar para assumir o Comando da Corporação, no ano de 1983. Esse período possibilita observar as comemorações em homenagem ao Patrono das Polícias como espaços de permanência de uma identidade institucional, em que o discurso sobre o herói reforça uma construção cultural que institui os militares como homens guerreiros e salvadores da Pátria.

No recorte temporal proposto, localizou-se apenas um discurso, que foi analisado tomando-se como principal suporte teórico os conceitos de gênero, memória e identidade. Com o objetivo de observar a permanência da construção discursiva apresentada nas Comemorações de Tiradentes, foram consultados discursos dedicados ao Patrono da Polícia Militar do Paraná e à própria Polícia Militar do Paraná, ${ }^{11}$ por ocasião das comemorações do seu aniversário, que reafirmam o discurso em homenagem ao Tiradentes. Dessa forma, os discursos são identificados como constituintes de uma identidade masculina e homogeneizante.

O herói Tiradentes representa o ideal de cidadão brasileiro, de militar, de policial e de religiosidade. Um homem

\footnotetext{
${ }^{10}$ Ordens do Dia são Boletins Especiais que veiculam textos comemorativos, os quais são assinados pelo Comando Geral e lidos durante as cerimônias realizadas pela Corporação, em todos os quartéis do Estado.

${ }^{11}$ Comemorações de 17 de maio, dia dedicado ao Patrono da Polícia Militar do Paraná, o Coronel Joaquim Antônio de Moraes Sarmento. POLÍCIA MILITAR DO PARANÁ. Boletim Especial . Curitiba, PR, nº 01, 17 de maio de 1978. POLÍCIA MILITAR DO PARANÂ. Boletim Especial. Curitiba, PR, nº 02, 17 de maio de 1979. Comemorações de 10 de agosto, aniversário da Polícia Militar do Estado do Paraná. POLÍCIA MILITAR DO PARANÁ. Boletim Especial. Curitiba, PR, nº 03, 10 de agosto de 1978. POLÍCIA MILITAR DO PARANÁ. Boletim Especial. Curitiba, PR, $\mathrm{n}^{\circ} 03,10$ de agosto de 1980.
} 
militar que morreu em defesa da pátria, e que, como Cristo, deu a vida pela humanidade. É o símbolo que identifica a Nação e as instituições que a cultuam e cria uma ideia de permanência da identidade do grupo. Essa identidade coletiva imutável é, para Joan Scott, uma invenção que oculta a descontinuidade na história, os conflitos e as diferenças; é uma fantasia ${ }^{12}$ reveladora de uma identidade fundada em valores e práticas historicamente identificados como masculinos.

Os espaços reveladores da identidade do herói são as comemorações. Elas atualizam o herói e possibilitam analisar as permanências das suas características identitárias. Para Raoul Girardet, "todo processo de heroificação implica (...) uma certa adequação entre a personalidade do salvador virtual e as necessidades da uma sociedade em um dado momento de sua história" ${ }^{13}$. A imagem do herói é reconstruída em função das necessidades, sendo revelador daqueles que constroem a sua imagem. Os espaços das comemorações perpetuam ou alteram a identidade do herói, dependendo do momento vivido pelo Estado ou pelas instituições que o cultuam.

As comemorações nacionais, segundo a historiadora Helenice Silva, são espaços de uma memória coletiva e de uma identidade nacional, que buscam no passado significações para o presente, eliminando as diferenças e contradições ligadas ao acontecimento do passado. "Comemorar significa, então, reviver de forma coletiva a memória e um acontecimento considerado como ato fundador (...)". ${ }^{14}$ Portanto, as Ordens do Dia e as comemorações dedicadas ao Tiradentes na Polícia Militar do Paraná são espaços de construção, manutenção e ressignificação de uma memória e de uma identidade institucional, a qual está ligada diretamente aos militares do Exército.

\footnotetext{
${ }^{12}$ SCOTT, Joan W. Fantasy Echo: história e a construção da identidade. Labrys: Estudos Feministas, n. ${ }^{\circ}$ 1-2, jul./dez. 2002.

${ }^{13}$ GIRARDET, Raoul. Mitos e mitologias politicas. São Paulo: Companhia das Letras, 1987. p. 82-83.

${ }^{14}$ SILVA, Helenice Rodrigues da. "Rememoração"/comemoração: as utilizações sociais da memória. Revista Brasileira de História, São Paulo, v. 22, n. ${ }^{\circ}$ 44, p. 425-438, 2002, p.432 
As cerimônias e as comemorações são, como sustenta Pierre Nora, lugares da memória. Os espaços do vivido são aqueles onde os grupos constroem suas origens e suas identidades ${ }^{15}$. São espaços da memória coletiva e da identidade do grupo. "A referência ao passado serve para manter a coesão dos grupos e das instituições que compõem uma sociedade"16, afirma Michael Pollak. Essas memórias são constituídas, segundo este autor, por três elementos: os acontecimentos, os personagens e os lugares. ${ }^{17}$ São construções que os grupos fazem de si próprios e que mantêm as identidades coletivas.

As identidades são interiorizadas e objetivadas nas relações estabelecidas em espaços sociais, no decorrer da trajetória social, e não estão livres das tensões e contradições existentes no processo de construção. Elas não existem fora dos espaços sociais e são relacionais, constituem-se nas relações que se estabelecem em diferentes espaços sociais. ${ }^{18}$ Dessa forma, uma mesma pessoa assume diferentes identidades, que existem em relação aos espaços sociais em que circula e em relação a outras identidades.

Ao pensar identidade e diferença, Stuart Hall identifica que as identidades estão em constante "processo de mudança e transformação" e são construídas dentro de discursos. Assim, para que se possa compreender as identidades e as diferenças, é preciso localizar os espaços de construção do discurso e identificar o jogo de poder e de exclusão que as significam. ${ }^{19}$ As identidades são o ponto de encontro entre

15 NORA, Pierre. Entre memória e história: a problemática dos lugares. Projeto História, São Paulo, n. ${ }^{\circ}$ 10, dezembro de 1993.

${ }^{16}$ POLLAK, Michael. Memória, esquecimento, silêncio. Estudos Históricos, n. ${ }^{\circ} 3$, v. 2, p. 3-15. p.9.

${ }^{17}$ POLLAK, Michael. Memória e identidade social. Estudos Históricos, n. ${ }^{\circ}$ 10, v. 5, p. 200-215, 1992. p.201-202.

${ }^{18}$ DUBAR, C. Trajetórias sociais e formas identitárias: alguns esclarecimentos conceituais e metodológicos. Educação e Sociedade, ano 19, n. ${ }^{\circ}$ 62, abril, 1998, p. 13-30. p.14-16.

${ }^{19}$ HALL, Stuart. Quem precisa de identidade? In: SILVA, T. (org.) Identidade e diferença: a perspectiva dos estudos culturais. Petrópolis:Vozes, 2000. p.108-109. 
as práticas e os discursos, isto é, são as posições ocupadas pelos sujeitos nos espaços sociais. ${ }^{20}$

Segundo Pierre Bourdieu, a construção das identidades é relacional e se estabelece no espaço do campo e a partir do habitus. Para ele, o espaço social é construído e é construtor de um sistema simbólico, que dá significação para práticas e símbolos, os quais são incorporados e identificam as pessoas que a ele pertencem, assim como permite que seja identificado por elas. ${ }^{21}$ Os significados das práticas de uma instituição só são percebidos a partir da análise do sistema simbólico que dá significação à cultura daqueles que as realizam. Esse sistema é reproduzido por meio da ação pedagógica, uma forma de violência simbólica que tem como objetivo impor um conjunto de significações identificadoras da cultura daqueles que a praticam e a mantêm. ${ }^{22}$

Os autores citados pensam a identidade enquanto uma construção social. Todavia, Pierre Bourdieu ao considerar o processo de construção social e incorporação subjetiva da identidade como espaço socialmente construído, aponta para a tendência de reprodução das relações sociais e, por conseguinte, dos sistemas simbólicos e das identidades. ${ }^{23} \mathrm{~A}$ herança de uma história e de uma tradição são centrais no processo de construção da identidade em uma instituição, ${ }^{24}$ a exemplo do que ocorre com Polícia Militar do Paraná em relação a Tiradentes.

A partir de tais afirmações, as comemorações de Tiradentes permitem problematizar a construção de uma identidade institucional vinculada ao gênero na Polícia Militar do Paraná, identidade essa compartilhada com os ideais pre-

\footnotetext{
${ }^{20}$ Ibid., p. 111-112.

${ }^{21}$ BOURDIEU, Pierre. O poder simbólico. Rio de Janeiro: Bertrand Brasil, 1998, p. 92-95.

22 BOURDIEU, P.; PASSERON, J. A reprodução: elementos para uma teoria do sistema de ensino. Rio de Janeiro: Livraria Francisco Alves, 1992, p. 22-23.

${ }^{23}$ BOURDIEU, Pierre. O poder simbólico. Rio de Janeiro: Bertrand Brasil, 1998, p. $141-145$

${ }^{24}$ BOURDIEU, Pierre. O poder simbólico. Rio de Janeiro: Bertrand Brasil, 1998, p. 87-88.
} 
sentes no Exército e no Estado. Considerando que no período analisado as Polícias Militares estavam subordinadas à Inspetoria Geral das Polícias Militares (IGPM) ${ }^{25}$, órgão ligado ao Exército, e aos Governadores dos Estados, os ideais de homem brasileiro expressos nas comemorações da Polícia Militar do Paraná são reveladores de uma masculinidade que é compartilhada por essas diferentes instituições de poder. Um modelo de masculinidade representado pelo homem guerreiro e capaz de morrer pela Pátria é central nos discursos do Exército e da Polícia Militar do Estado do Paraná, o qual oculta as diferenças e as mudanças que ocorriam dentro e fora dos quartéis, bem com as diferentes identidades que as pessoas assumem em suas trajetórias.

As comemorações institucionais tendem a exaltar a nação e a personalidade do herói e são espaços de construção de significados das diferenças percebidas entre os sexos. ${ }^{26}$ A análise desse elemento simbólico, que é um lugar da memória, possibilita o reconhecimento da identidade coletiva institucional, que se constitui em relação a identidades de gênero. $\mathrm{O}$ espaço institucional é constituído por um conjunto de elementos herdados do passado, o qual se altera ou se mantém durante o processo de desenvolvimento das relações que se estabelecem harmônica e conflituosamente no conjunto da instituição, formado pelos espaços físico da mesma (a arquitetura e a divisão espacial do edificio institucional), pelas legislações, pelas cerimônias, pela hierarquia, pelo ingresso de novos membros e pela ligação com outros espaços que com ela se relacionam. As modificações em um símbolo institucional indicam alterações no espaço institucional, como afirmam Eric Hobsbawm ${ }^{27}$ e Raul Girardet ${ }^{28}$.

\footnotetext{
${ }^{25}$ A IGPM foi criada em 1967 e em 1969 foi integrada ao Estado Maior do Exército. O cargo de Inspetor Geral era exercido por um General de Brigada.

${ }^{26}$ Ver: SCOTT, Joan W. Prefácio a Gender and Politics of History, Cadernos Pagu, n. ${ }^{\circ} 3,1994$, p. 11-27.

${ }^{27}$ HOBSBAWM, Eric. A invenção das tradições. Rio de Janeiro: Paz e Terra, 2002 .

${ }^{28}$ GIRARDET, Raul. Mitos e mitologias políticas. São Paulo: Cia das Letras, 1987.
} 
No dia 9 de abril de 1980 publicou-se, no Boletim da corporação, um documento do Ministério do Exército contendo orientações para a realização das comemorações do Dia de Tiradentes. Segundo o texto, o Ministro do Exército "resolve":

Determinar aos Exércitos e Comandos Militares de Área que comemorem o Dia do Patrono Cívico da Nação Brasileira obedecendo à seguinte programação mínima:

1. Realização de palestras, nas Organizações Militares, sobre a vida de Tiradentes, focalizando sua contribuição para a Independência do Brasil e seu arraigado amor à liberdade - características intrínsecas do nosso povo.

2. Apoio dos comandados subordinados às cerimônias programadas pelas Polícias Militares Estaduais.

3. Estímulo e apoio às autoridades governamentais estaduais e municipais, estabelecimentos de ensino, clubes de serviço, entidades de classe, para realização de atos cívicos destinados a reverenciar a figura de Tiradentes. ${ }^{29}$

Esse documento indica que havia preocupação com a realização e o controle sobre as comemorações, dentro e fora dos espaços militares. O herói possui, segundo o texto, características que pertencem ao povo brasileiro. A figura de Tiradentes representa uma identidade nacional, cujas caracteristicas identificadoras pertencem também ao herói que é um modelo a ser seguido, como se identifica na citação:

- Tiradentes foi o precursor da grande luta pela Independência da Pátria, sacrificando sua própria vida (...);

- a morte infamante a que foi condenado representa, na verdade, a glorificação de sua vida como Protomártir de nossa independência;

- os ideais de liberdade, pelos quais pugnou Tiradentes, num exemplo inexcedível de coragem, abnegação e patriotismo, constituem valioso patrimônio da Nação, que devem ser preservados;

${ }^{29}$ POLÍCIA MILITAR DO PARANÁ. Boletim Geral. Curitiba, PR, nº 67, 9 de abril de 1980 , p. 2-3. 
- o Exército tem o dever indeclinável de cultuar a memória dos grandes vultos nacionais, apontando-os como exemplos às novas gerações de soldados; (...). ${ }^{30}$

Observa-se a permanência de ideais que remetem a uma identidade militar construída entre o final do século XIX e início do século XX. O sacrificio do herói em defesa da liberdade da Pátria e sua coragem são valores que devem ser incorporados pelas novas gerações de soldados. Afirmações que indicam uma aparente permanência de valores e ideais em relação ao passado e que estão ligados à instituição militar e à identidade nacional. As características do herói são percebidas como identificadoras dos conceitos de povo brasileiro, de militar e de masculinidade.

A identidade militar construída pelo Exército também se manifesta na Polícia Militar do Paraná. Uma identidade construída por um ideal de masculinidade e uma visão de História, pautada pelos acontecimentos políticos e militares, logo uma História feita por homens. Os heróis são os responsáveis pela indicação do caminho. O presente é herdeiro dos ensinamentos dos heróis do passado, principalmente do Patrono da Nação Brasileira, o Tiradentes.

Além do mais, é preciso considerar que na Polícia Militar do Paraná essa herança não se constituiu nas relações estabelecidas entre as instituições militares durante a Ditadura Militar. A ligação entre a corporação policial e o Exército está relacionada à criação da Força Policial no Paraná, no século XIX, e à construção do herói Tiradentes.

A ideia dos militares enquanto um grupo responsável pela Pátria é uma construção que nasceu no século XIX e se firmou na primeira metade do século XX, segundo o estudo de Miriam de Oliveira Santos. Para a autora, entre 1870 e 1930, constituiu-se a ideia do Exército "como interventor a serviço da ordem" ${ }^{31}$, que é parte da imagem e da identidade militar brasileira do século XX. A honra e a virilidade são

\footnotetext{
${ }^{30}$ Idem.

${ }^{31}$ SANTOS, Miriam de Oliveira. Berços de Heróis: o papel das escolas militares na formação de "salvadores da Pátria". São Paulo: Annablume, 2004, p.16-17.
} 
algumas das características da identidade coletiva militar, bem como as concepções de "salvadores da Pátria"32.

Para Pedro Paulo de Oliveira, a construção dos Estados Nacionais Europeus, no século XIX, esteve ligada à organização dos exércitos nacionais. Os ideais de pátria e nação, forjados no decorrer do século XIX e início do XX, foram significados em relação às ideias de militarização, de nacionalismo e de masculinidade. Os estados autoritários do início do século XX, marcados por ideais nazistas, fascistas e socialistas, reforçam os ideais de masculinidade, isto é, a lealdade, a disciplina, a obediência, a coragem de morrer em defesa da pátria. ${ }^{33}$ Identifica-se que a construção das identidades dos Estados Nacionais está marcada pelo gênero, assim como estão elas relacionadas à identidade militar.

No Brasil essas ideias ficam mais aparentes a partir da década de 1930, com o governo de Getúlio Vargas, que se inspirou em modelos nacionalistas europeus. As comemorações cívicas e as paradas militares, que são espaços de representação do ideal de nação e de cidadão, ganharam outra dimensão no Governo Vargas, que instituiu a "Semana de Tiradentes". Essas comemorações dedicadas a Tiradentes foram importantes na construção de uma representação de nação e de uma identidade nacional, se consideramos os documentos publicados pela Polícia Militar do Paraná ${ }^{34}$.

Nos anos de 1970, segundo José Murilo de Carvalho, Tiradentes foi apropriado pela esquerda. Um dos movimentos guerrilheiros que lutaram contra o regime militar "adotou seu nome"35. Essa apropriação do herói por diferentes instituições expressa a ambigüidade do mito que representa diferentes modelos a serem incorporados, entre os quais o ideal de guerrilheiro, de policial militar e de soldado do Exército.

\footnotetext{
${ }^{32}$ Ibid., p.16-17.

33 OLIVEIRA, Pedro P. de. A construção social da masculinidade. Belo Horizonte: Ed. UFMG; Rio de Janeiro: IUPERJ, 2004, p. 26-46.

${ }^{34}$ Consultados os Boletins entre 1930 e 1940. Arquivo Geral da Polícia Militar do Paraná. Curitiba.

${ }^{35}$ CARVAlHO, José. M. de. A formação das almas: o imaginário da República no Brasil. São Paulo: Cia das Letras, 1998, p. 71. 
Seguindo as determinações do Ministério do Exército, no dia 21 de abril do ano de 1980, em Boletim Especial, a Polícia Militar do Estado do Paraná publicou o discurso do Coronel do Exército Brasileiro Manoel Abreu de Moraes, Comandante da Polícia Militar do Estado do Paraná, em homenagem ao Patrono das Polícias Militares. No início do texto, o Comandante Geral afirma que "os policiais o escolheram porque, naturalmente, se identificaram com as qualidades e virtudes que lhe ornaram a personalidade quando em vida" ${ }^{36}$, lembrando aos policiais que foram eles que o escolheram como herói e modelo a ser seguido; logo, eles devem incorporar suas virtudes e qualidades.

As cerimônias e os símbolos são importantes para uma instituição inscrever seus códigos e regulamentos nos corpos de seus membros, mas também são acontecimentos que contam a história institucional. Nesse sentido, o simbólico faz parte de um aparato pedagógico construtor de identidades nas instituições. É o espaço de incorporação do discurso da lei. A lei, para Michel de Certeau, muda os espaços sociais e os organiza a partir da inscrição do seu texto em seres sociais, que são aceitos e reconhecidos naquele espaço. O processo de inscrição da lei ocorre por aparelhos de mediação entre o que está posto e os espaços sociais. ${ }^{37}$

A Ditadura Militar no Brasil foi um período marcado pela ação repressiva do Estado, que dispunha das polícias militares como um dos braços do aparato repressivo. Durante esse processo, o Estado Brasileiro criou dispositivos para justificar as medidas e ações do Regime expressas na legislação, ${ }^{38}$ do qual fizeram parte a propaganda e as comemorações dirigidas aos heróis, que foram importantes ferramentas para a sua legitimação.

${ }_{36}$ POLÍCIA MILITAR DO PARANÁ. Boletim Especial. Curitiba, PR, nº 01, 21 de abril de 1980.

${ }^{37}$ CERTEAU, Michel de. A invenção do cotidiano. Artes de fazer. v.1. Petrópolis: Vozes, 1994, p. 230-235.

${ }^{38}$ REZENDE, Maria José de. A ditadura militar no Brasil: repressão e pretensão de legitimidade. Londrina: Ed. UEL, 2001. 
Outra ferramenta construtora e reprodutora das identidades coletivas são as escolas. Elas são espaços, segundo Pierre Bourdieu, que contribuem para a reprodução do social. ${ }^{39}$ No caso das instituições militares, as Escolas de Militares tendem a reproduzir as identidades coletivas e os valores identificadores da corporação e de seus membros. Devido a uma questão geracional, a identidade institucional, que remonta ao século XIX, permanece presente nas ideias da Escola Superior de Guerra, nos anos de 1970. Os ideais e a identidade construída nas décadas de 1920 e 1930 fazem parte do projeto político do Exército das décadas de 1960 e 1970.

A idealização dos homens militares como protetores e responsáveis pela Nação e pelo povo brasileiro, bem como partes de uma elite incumbida da modernização do País, são preceitos identificados na Doutrina Básica da Escola Superior de Guerra, de $1979^{40}$. Segundo esse documento, "cabe à elite o papel de captar e interpretar os autênticos interesses e aspirações nacionais (...)"11 e os militares são parte dessa elite. Para a Escola Superior de Guerra, a História brasileira demonstra a importância do papel das elites para a nação e um dos principais movimentos históricos citados na Doutrina é a Inconfidência Mineira ${ }^{42}$, da qual surgiu o personagem Tiradentes.

Esses indícios apontam para a construção da identidade militar, a qual se confunde com a construção da identidade nacional brasileira, ambas identidades coletivas pautadas na masculinidade. A nação e as instituições militares que fazem sua História são espaços para homens. Espaços que excluem a participação das mulheres, bem como constroem

\footnotetext{
${ }^{39}$ BOUDIEU, Pierre. Razões práticas: sobre a teoria da ação. Campinas: Papirus, 1996, p. 35.

${ }^{40}$ OLIVEIRA, Lucia Maciel Barbosa de. "Nossos comerciais por favor!": A televisão brasileira e a Escola Superior de Guerra - o caso Flávio Cavalcanti. São Paulo: Beca, 2001.

${ }^{41}$ ESCOLA SUPERIOR DE GUERRA. Doutrina Básica. Rio de Janeiro, 1979, p. 29.

${ }^{42}$ Ibid., p. 41-47.

166 Revista de História Regional 14(2): 154-177, Inverno, 2009
} 
as categorias homem, militar e povo com características homogeneizantes, livres de contradições e diferenças.

A construção da História como uma prática de homens militares é central na memória coletiva e na identidade militar. O espaço dos quartéis, a farda, a arma e a violência são domínios de homens militares, responsáveis pela modernização da nação. O povo não participa da história, pois, segundo a Escola Superior de Guerra, ele "não percebeu a importância de certos interesses (...). Impõe-se, então, um processo pedagógico para que a comunidade nacional aceite tais interesses e compreenda a necessidade de seu atendimento." ${ }^{43}$ Durante o Regime Militar, coube à elite militar zelar pelos interesses da nação e agir para que a "comunidade nacional" aceitasse o projeto de nação que estava sendo construído. Além do mais:

A Doutrina de Segurança Nacional estudada na ESG alicerça-se na crença da Democracia como regime político por excelência, de vez que se fundamenta no respeito à dignidade da pessoa humana, nos valores morais e espirituais da nacionalidade e que busca incessantemente o Bem Comum. ${ }^{44}$

A referência constante à defesa da democracia e à "construção de um suposto ideário de democracia" foi uma estratégia do Regime Militar para buscar a legitimidade da ditadura, segundo Maria José de Rezende. Os valores ligados à pátria, aos militares, à família e à religião, foram utilizados como identificadores do regime. ${ }^{45}$

Essa era a característica da doutrina da Escola Superior de Guerra, que tinha como principal objetivo o "bem comum". Para defender os interesses nacionais era necessário combater o inimigo. "Sem ordem não há desenvolvimento e sem desenvolvimento a segurança nacional está seria-

\footnotetext{
${ }^{43}$ ESCOLA SUPERIOR DE GUERRA. Doutrina Básica. Rio de Janeiro, 1979, p. 28.

${ }^{44}$ ESCOLA SUPERIOR DE GUERRA. Manual Básico. Rio de Janeiro, 1975, p. 259.

${ }^{45}$ REZENDE, Maria J. de. A Ditadura Militar no Brasil: repressão e pretensão de legitimidade (1964-1984). Londrina: Ed. UEL, 2001, p. 2-3.
} 
mente ameaçada, vulnerável à infiltração e assentamento do inimigo". ${ }^{46}$ As instituições policiais militares foram utilizadas para manter a ordem e a segurança da nação, contribuindo para o projeto nacional da Escola Superior de Guerra. Um projeto, segundo Lucia Maciel Barbosa de Oliveira, "embasado por um universo de valores extremamente conservador, de linhagem cristã-ocidental, que tem na família, na pátria, na propriedade, na religião, na moral e bons costumes, os pilares da ordem social (...)" ${ }^{\prime 4}$. Assim como a identidade militar, o projeto nacional é homogeneizante.

Essas ideias da Escola Superior de Guerra, que apresentam a sociedade como homogênea, em que o espaço público é destinado aos homens, são identificadas na Ordem do Dia dedicada a Tiradentes no ano de 1980. Nesse discurso, que deveria ser lido em todos os quartéis da Polícia Militar do Estado do Paraná, o Comando Geral fala em nome da instituição policial militar, do Estado do Paraná e do Exército Brasileiro, afirmando o ideal a ser seguido pelos policiais. As qualidades e as virtudes que identificam um policial militar são atribuídas ao herói, que representa o modelo a ser seguido, pois ele agiu como um policial militar agiria.

Essa Ordem do Dia, composta por três páginas, elenca as virtudes e qualidades do herói, que são descritas em resposta a uma questão colocada no segundo parágrafo, em que o Comandante Geral fez a seguinte indagação:

Que virtudes do vulto maior, do vulto principal da Inconfidência Mineira fizeram com que Policiais Militares as adotassem como objetivo de vida profissional a atingir, a conquistar, a desenvolver, e a cultuar no mais alto grau? ${ }^{48}$

\footnotetext{
${ }^{46}$ OLIVEIRA, Lúcia Maciel Barbosa de. "Nossos comerciais por favor!": a televisão brasileira e a Escola Superior de Guerra - o caso Flávio Cavalcanti. São Paulo: Beca Produções Culturais, 2001, p. 36.

${ }^{47}$ OLIVEIRA, Lúcia Maciel B. de. "Nossos comerciais por favor!": a televisão brasileira e a Escola Superior de Guerra - o caso Flávio Cavalcanti. São Paulo: Beca Produções Culturais, 2001, p.17.

48 POLÍCIA MILITAR DO PARANÁ. Boletim Especial. Curitiba, PR, nº 0121 de abril, 1980
} 
Como resposta a essa pergunta, segue a descrição das qualidades e virtudes do herói, das quais algumas aparecem grifadas, sugerindo que são as mais importantes. Uma leitura dos grifos possibilita construir uma descrição do padrão de policial militar. Sendo assim, um policial deveria seguir o exemplo do homem e herói Tiradentes, possuidor de "força de vontade", "caráter nobre, fogoso e aventureiro" e "dotado de enorme entusiasmo". Um "Homem profundamente cristão, equilibrado e sereno", de "personalidade marcante, límpido ideal, desprendido e dotado de um enorme espírito de sacrificio". Um "amigo do povo, perscrutador atento de sofrimentos e anelos", "homem desinteressado de bens materiais", que dedicou sua vida a "amar a sua terra e a sua gente". ${ }^{49}$

Esse ideal de homem representado pela descrição do herói deveria ser incorporado pelos policiais militares. Assim como Tiradentes, o policial militar deveria ser um homem viril, cristão e desapegado do mundo material. Teria sido por se identificaram com ele que os policiais escolheram-no como um dos heróis da corporação. Assim como Tiradentes, que dedicou sua vida ao povo, também os homens da Polícia Militar devem ter tal dedicação.

Deixou Tiradentes, como se vê, rica e fecunda herança espiritual a seus afiliados, os Policiais Militares. E à Polícia Militar do Paraná cabe honrar esta herança com fidelidade, tendo-a sempre em mente como objetivo a conquistar, e nesta caminhada, buscar torná-la um modo de vida e de ação constantes. ${ }^{50}$

Essa identidade de policial militar expressa no texto em questão é pautada pelo ideal de militar construído pela Escola Superior de Guerra. As características identificadoras da masculinidade, como a honra, a coragem e o espírito de sacrificio, são as qualidades do herói. Essa memória coletiva se mantém no Exército, na Polícia Militar do Paraná e nas outras polícias militares brasileiras. O espaço militar é identificador de masculinidade e de uma identidade nacional.

\footnotetext{
${ }^{49}$ Idem.

${ }^{50}$ Idem.
} 
A virilidade é um aspecto central nessa construção. Os membros das instituições militares são os responsáveis pelo povo. São homens honrados, desprendidos e possuidores de espírito de sacrificio. Tais características são identificadoras de um ideal de masculinidade e da identidade do militar. Porém, mudanças na legislação das polícias militares abriram a possibilidade para a criação das corporações policiais femininas no Brasil e, portanto, esse espaço, culturalmente identificado como dominio de homens responsáveis pela Pátria, passou a incorporar mulheres.

Em um periodo marcado pelo Movimento Feminista e pelo crescimento da participação de mulheres em vários espaços sociais, dentre os quais as organizações guerrilheiras ${ }^{51}$, a Escola Superior de Guerra via as mulheres como principais responsáveis pela permanência da família, que era identificada como uma das instituições básicas da sociedade, assim como uma das responsáveis pela tradição e a transmissão da moral e dos bons costumes. O trabalho das mulheres fora de casa, segundo o Manual Básico da Escola Superior de Guerra, "contribui para enfraquecer a coesão familiar"52. O ideal de mulher descrito nesse Manual pressupõe uma permanência dos papéis tradicionais de feminilidade, isto é, mãe e esposa, responsável pelo espaço privado.

Alterações na legislação de Organização Básica da Polícia Militar do Paraná de 1976 possibilitaram a criação da Polícia Feminina, em 1977. Segundo o texto da lei, "a criação de organização policial-militar feminina será feita pelo Governador do Estado, ouvidos os órgãos federais competentes" ${ }^{3}$. Com relação a esta última ressalva, entenda-se que se trata da Inspetoria Geral das Polícias Militares. Em 16 de junho de 1977, esse órgão federal baixou uma portaria, regulamentando a Organização das Polícias Militares e dos Corpos de

\footnotetext{
${ }^{51}$ WOLFF, Cristina Scheibe. Feminismo e configurações de gênero na guerrilha. Revista Brasileira de História, n. ${ }^{\circ}$ 54, v.27, p. 19-38, 2007.

52 ESCOLA SUPERIOR DE GUERRA. Manual Básico. Rio de Janeiro, 1975. p. 399

53 ESTADO DO PARANÁ. Lei $n .^{\circ}$ 6.774, Lei de Organizações Básicas da Polícia Militar do Paraná,, Curitiba, 8 de janeiro de 1976, art. 72.
} 
Bombeiros Militares, a qual incluiu a "Polícia Feminina", com o objetivo de atuar junto a "menores delinquentes ou abandonados e com mulheres envolvidas em ilícitos penais". Cabia às mulheres policiais agirem em atividades que, segundo o texto da lei, o "policiamento ostensivo" encontrava dificuldades, assim como em "certos tipos de relações com determinados públicos" ${ }^{4}$. Na organização da "Polícia Feminina", as Polícias Militares deveriam em seguida criar "organizações de Polícia Feminina com determinados graus hierárquicos, assemelhados ao da hierarquia militar" ${ }^{55}$.

Em 19 de abril de 1977, o Governo do Estado do Paraná criou o Pelotão de Polícia Feminina ${ }^{56}$, segundo as normas ditadas pela Inspetoria Geral das Polícias Militares e pela Escola Superior de Guerra. Nesse período, entre 1976 e 1977, a Polícia Militar do Paraná passou por uma reestruturação. Foram criados dois comandos de policiamento: o da Capital, com jurisdição sobre a área de Curitiba e região metropolitana, e outro, o do Interior, com jurisdição sobre o restante do território do Estado. Além do mais, são criados Batalhões em Campo Mourão e Apucarana, bem como Companhias Independentes na Lapa, em União da Vitória, em Guarapuava e em Foz do Iguaçu, conforme anteprojeto de 1976, encaminhado pelo Governador Jayme Canet Junior ao General da

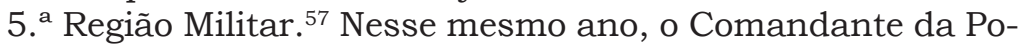
lícia Militar do Paraná, tendo como referência o anteprojeto citado, solicita a criação de um Pelotão de Polícia Feminina. Em 31 de março de 1977, o General Ruy de Paula Couto aprovou o anteprojeto e em 19 de abril de 1977 foi publicado o decreto de reorganização da Polícia Militar do Paraná.

\footnotetext{
${ }^{54}$ IGPM. Portaria n. $^{\circ}$ 27, Organização das Polícias Militares e dos Corpos de Bombeiros Militares, Brasília, 16 de junho de 1977, capitulo III, item 22, p. 16. (arquivo da $1 .^{\text {a }}$ Seção do Estado Maior da Polícia Militar do Paraná)

${ }^{55}$ Idem.

${ }^{56}$ POLÍCIA MILITAR DO PARANÁ. Boletim Geral. Curitiba, PR, n. ${ }^{\circ} 78,27$ de abril de 1977, p. 3-4. (Arquivo Geral da Polícia Militar do Paraná)

${ }^{57}$ ESTADO DO PARANÁ. Oficio $n .^{\circ}$ 995/76. Curitiba, 8 de junho de 1976. Anteprojeto de reorganização da Polícia Militar do Paraná. (Arquivo da 1. ${ }^{a}$ Seção do Estado Maior da Polícia Militar do Paraná, v. 29, p. 109-112.)
} 
O reconhecimento e aceitação do ingresso da mulher em espaços até então "reservados ao sexo masculino"58 encontrava-se no Manual Básico da Escola Superior de Guerra do ano de 1975. Todavia, o mesmo documento afirma que a família é enfraquecida com o trabalho da mulher fora de casa e que, no espaço público, é "nos empreendimentos comunitários" 59 que ela se destaca. Mesmo admitido a presença de mulheres em espaços tradicionalmente masculinos, o que se reafirma é a relação da mulher com a maternidade.

Os espaços que até aquele momento eram exclusividade do sexo masculino também passaram a ser ocupados pelas mulheres. Porém, as atividades desempenhadas pelas mulheres no espaço militar reproduzem as identidades tradicionais e historicamente construídas e identificadoras de um ideal de feminilidade e outro de masculinidade. Como se observou no discurso de comemoração ao Dia de Tiradentes, a Polícia Milita do Estado do Paraná manteve sua identidade institucional fundada em ideais de masculinidade e identificando seus membros como homens.

Embora não se tenham localizado mais discursos dedicados ao Tiradentes no período analisado, observando outras Ordens do Dia publicadas para fins comemorativos, identifica-se que não ocorreu alteração no ideal de policial militar. Os discursos são dirigidos aos homens da instituição e as qualidades identificadoras do policial militar remetem a um ideal de masculinidade. A presença da "polícia feminina" - nome que identificava o espaço da mulher na instituição, do qual foi retirado o adjetivo militar, o que marca a diferença em relação ao "policial militar" - com certeza incomodava os homens policiais militares. Elas não aparecem nas comemorações, bem como as características identificadoras do feminino na instituição, que estão relacionadas às atividades que lhes são destinadas.

\footnotetext{
58 ESCOLA SUPERIOR DE GUERRA. Manual Básico. Rio de Janeiro, 1975. p. 399

${ }^{59}$ Idem.

172 Revista de História Regional 14(2): 154-177, Inverno, 2009
} 
Na legislação da Polícia Feminina de 1979 foram definidos os espaços que as mulheres ocupariam dentro da corporação paranaense e as atividades a elas destinadas compõem o principal identificador do que pertencia ao feminino dentro da corporação. Segundo o texto da Diretriz n. ${ }^{\circ}$ 076/79, a Polícia Feminina tinha por "finalidade básica (...) orientar, proteger e informar a população, especialmente o menor, $\underline{\text { a }}$

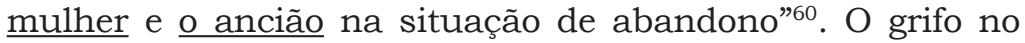
texto original marca o espaço de atividades femininas, assim como a população a que se destinavam as atividades das policiais. Atividades, aliás, tradicionalmente destinadas ao sexo feminino e principalmente relacionadas a uma ideia de maternidade. As policiais representavam a imagem maternal da corporação.

Em seu estudo sobre o ingresso de mulheres na Polícia Militar do Paraná, a historiadora Rosimeri Moreira afirma que "a mulher-policial é pensada simbolicamente na legislação normatizadora com a função da maternagem: 'mãe'-militarizada que protege/cuida, orienta/direciona e informa/ forma" ${ }^{1}$. Funções que são destinadas às mulheres segundo o pensamento da Escola Superior de Guerra. Como afirma Lucia Maciel Barbosa de Oliveira, elas "são vistas como receptoras e transmissoras da tradição, cabendo-lhes o papel de manutenção da ordem social idealizada"62.

As atividades a serem desempenhadas pelas polícias femininas são identificadoras de uma identidade de gênero. As policiais tinham como função estabelecer relacionamentos com pessoas que, de certa forma, estão ligadas à esfera do privado. Porém, deveriam agir como assistentes sociais e na prevenção e combate ao crime junto a essa população. Considerando que a prática de cuidar de crianças é histori-

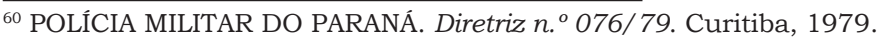

${ }^{61}$ MOREIRA, Rosemeri. "Entre o escudo de minerva e o manto de Penélope": a inclusão de mulheres na Policia militar do Estado do Paraná (1975-1981). Maringá, 2007. Dissertação (mestrado) - UEM, p. 91.

${ }^{62}$ OLIVEIRA, Lúcia Maciel B. de. "Nossos comerciais por favor!": a televisão brasileira e a Escola Superior de Guerra - o caso Flávio Cavalcanti. São Paulo: Beca Produções Culturais, 2001. p. 20. 
camente ligada a uma atividade destinada às mulheres e o combate ao crime seja uma atividade destinada aos homens, a policial feminina é um policial diferente. As mulheres pertencem a uma organização de Polícia Feminina, cuja estrutura "se assemelha" ${ }^{63}$ à organização militar masculina, mas não é a Polícia Militar, apenas faz parte da corporação, que continuou sendo um espaço de homens. Porém, para que fossem reconhecidas como policiais femininas, precisaram incorporar características e símbolos até então destinados aos homens. Entre essas características estão: a hierarquia, a disciplina e a farda. A arma é um símbolo da virilidade que lhes foi negado pela legislação.

É uma organização militarmente disciplinada, cujas componentes não portam ostensivamente armas, mas aprendem a manejar o armamento de uso individual e fazem largo uso dos meios de defesa pessoal para os casos de emergência. ${ }^{64}$

O uso da força e da violência, monopolizados pelo Estado, foram negados às mulheres policiais. "A Polícia Feminina não é uma organização de mulheres masculinizadas, fisicamente super desenvolvidas e agressivas." ${ }^{65}$ Sua função é maternal, isto é, "não se destina a efetuar prisão de criminosos ou de interferir em distúrbios e arruaças" ${ }^{\prime 6}$. Porém, a mesma legislação afirma que: "Respeitadas as diferenças biológicas, são exigidos da policial militar os mesmos padrões de desempenho profissional atribuídos ao policial-militar do sexo masculino" 67 .

Essa contradição entre ser feminina e igualar-se em desempenho profissional ao sexo masculino é reveladora de alterações nas identidades de gênero. Mesmo apropriando-se de ideais de feminilidade e de masculinidade impostos pela Ditadura, a Polícia Militar faz parte de um processo de alteração nos espaços ocupados por homens e mulheres. To-

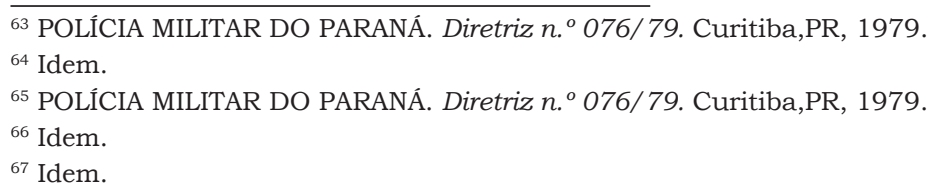


davia, o ideal da corporação como um espaço de virilidade permanece inalterado. Cabe às mulheres incorporar, em parte, esses elementos identificadores da masculinidade para serem reconhecidas no espaço masculino.

A incorporação de características identificadoras da masculinidade por mulheres que ingressaram em espaços identificados como pertencentes aos homens foi e continua sendo problematizada por diferentes campos da produção acadêmica. Entre os estudos relacionados ao ingresso de mulheres em espaços militarizados ${ }^{68}$ está o recente artigo de Cristina Scheibe Wolff, que é um estudo das "interfaces entre o feminismo de segunda onda e as configurações de gênero na guerrilha urbana durante o regime de Ditadura Militar (...)"69. Ela reconheceu a honra, a coragem, o espírito de sacrificio, a dignidade, a abnegação e a disciplina como características identificadoras da virilidade na guerrilha. ${ }^{70}$ As mesmas características são encontradas no ideal de militar da Escola Superior de Guerra e na Polícia Militar do Paraná. Para serem aceitas e reconhecidas nesses espaços masculinos, as mulheres precisam assumir as características identificadoras da masculinidade, porém não deixam de ser associadas ao feminino. O espaço das armas e da guerra culturalmente se constituiu como identificador de masculinidade e dominio dos homens.

A memória e a identidade institucional, expressas nas comemorações de Tiradentes na Polícia Militar do Paraná, são uma herança dos ideais de cidadão e de militar fundado na virilidade. Os acontecimentos rememorados são

\footnotetext{
${ }^{68}$ Ver: SOARES, Barbara M; MUSUMECI, Leonarda. Mulheres Polícias: presença feminina na Policia Militar do Rio de Janeiro. Rio de Janeiro: Civilização Brasileira, 2005. CALAZANS, Márcia Esteves de. A constituição de mulheres em policiais: um estudo sobre policiais femininas na Brigada Militar do Rio Grande do Sul. Porto Alegre, 2003. Dissertação (mestrado) - UFRG. D’ARAUJO, Maria C. Mulheres, homossexuais e Forcas Armadas no Brasil. In: CASTRO, Castro; IZECKSOHN, Victor; KRAAY, Hendrik. Nova história militar brasileira. Rio de Janeiro: Editora FGV, 2004. p.439-459. Para citar alguns trabalhos.

${ }^{69}$ WOLFF, Cristina Scheibe. Feminismo e configurações de gênero na guerrilha. Revista Brasileira de História, n. ${ }^{\circ}$ 54, v.27, p 19-38, 2007. p.19.

${ }^{70}$ Idem.
} 
marcados por personagens homens e o espaço do quartel é identificado como pertencente aos homens. As policiais femininas são excluídas da identidade institucional, pois os espaços das armas, do heroísmo e do Estado pertencem aos homens, logo, são identificadores da masculinidade. A construção simbólica do mito apresentada nos discursos remete à coragem, à abnegação e à bravura, atributos culturalmente identificados como pertencentes aos homens. Considerando a observação de Michelle Perrot quanto ao fato de que "a imagem da mulher-soldado" tornou-se insuportável ao século $\mathrm{XIX}^{71}$, e observando os discursos aqui analisados, é possível afirmar que essa imagem continuava insuportável no final do século XX.

O ingresso de mulheres na Polícia Militar do Paraná não alterou a memória e a identidade institucional apresentadas nas comemorações. Os movimentos sociais que ocorrem na sociedade brasileira entre o final dos anos de 1970 e a década de 1980, um periodo marcado pela transição de um regime de Ditadura Militar para a democracia ${ }^{72}$ e pela organização de movimentos de mulheres e pelo feminismo, não influenciaram na construção da memória e da identidade coletiva da Polícia Militar do Paraná, que permaneceram inalteradas. A Polícia Militar manteve a identidade coletiva marcada por características identificadoras de masculinidade e a referência à instituição como espaço de homens.

\footnotetext{
${ }^{71}$ PERROT, Michelle. Modernidades. In: FRAISSE, G; PERROT, M. (dir.) História das mulheres no Ocidente: O século XIX. Porto: Afrontamento, 1991. p. 503-540; p. 533.

${ }^{72}$ Ver: ABREU, Alzira Alves (org.). A democratização no Brasil: autores e contextos. Rio de Janeiro: Editora FGV, 2006. 


\section{As comemorações de Tiradentes: memória e identidade de gênero na Polícia Militar do Paraná}

Andréa Mazurok Schactae

Resumo: As comemorações em homenagem a Tiradentes, na Polícia Militar do Paraná, entre 1977 e 1983, possibilitam problematizar a existência de uma memória e de uma identidade institucional generificada, que se relacionam aos ideais da Escola Superior de Guerra e do Regime Militar. A existência de um Pelotão de Polícia Feminina, desde 1977, não alterou a memória e a identidade institucional identificadas nessas homenagens ao Patrono das Polícias Militares do Brasil, pois a Polícia Militar continua se apresentando como um espaço destinado a homens, como Tiradentes.

Palavras-chave: Comemorações; identidades; polícia feminina.

Abstract: The celebration in honor to Tiradentes, at the Paraná State Police Force, between 1977 and 1983, made it possible to problematize the existence of a memory and a genre institutional identity, which is related to the ideals of the Superior School of War and the Brazilian Military Regime. The existence of a Female Police Force since 1977 did not change the memory and institutional identity characterized in these homages to the Brazilian Military Police Patron, for the Military Police is still being presented as a space destined to men such as Tiradentes.

Keywords: Celebration; identities; female police.

Artigo recebido para publicação em 28/06/2009

Artigo aceito para publicação em 18/11/2009 